\title{
The Quality of Participatory Processes in the Urban Redevelopment Policy of Madrid City Council
}

\section{Gema SÁnCHez Medero \& Gema PAStor Albaladejo}

\begin{abstract}
The local sphere is the participatory space par excellence. However, there are few academic studies on citizen participation in urban polities, and even less on the quality of participatory mechanisms. This article analyses two participatory processes of urban reorganisation led by the City of Madrid, based on the development of an analytical framework designed to evaluate its quality, with the objective of knowing which initiative enjoys the higher quality, and of proposing a series of recommendations that would contribute to ensuring the successful development of these processes.
\end{abstract}

Keywords: $\bullet$ citizen participation $\bullet$ local administration $\bullet$ co-decision $\bullet$ public policy $\bullet$ city council $\bullet$ Madrid

Correspondence Address: Gema Sánchez Medero, Ph.D., Professor, Complutense University of Madrid, Faculty of Social Work, Complutense Public Administration Science Institute, Campus de Somosaguas, s/n, 28223 Pozuelo de Alarcón, Spain, email: gsmedero@cps.ucm.es. Gema Pastor Albaladejo, Ph.D., Professor, Complutense University of Madrid, Faculty of Political and Social Science, Complutense Public Administration Science Institute, Campus de Somosaguas, s/n, 28223 Pozuelo de Alarcón, Spain, email: artis@cps.ucm.es.

https://doi.org/10.4335/16.4.841-872(2018)

ISSN 1581-5374 Print/1855-363X Online C) 2018 Lex localis

Available online at http://journal.lex-localis.press. 
In recent times, citizen participation has surpassed its traditional and classic electoral conception, turning into a "magical formula" to resolve the multiple, complex, diverse and interconnected political problems (governability crisis and political and social legitimacy deficits). social problems (lack of inclusion and social cohesion) managerial problems (inefficient and ineffective public policies) that in the current context undermine the stability of governments and public administrations (Pastor Albaladejo, 2013a: 196).

As a result, participation stands out for being a ubiquitous term, in academic circles as well as in political and administrative practice. From an academic perspective, different theories of democracy ("quality of democracy", "participatory democracy" and "deliberative democracy") view participation as a fundamental dimension to evaluate democratic quality, as well as a fundamental concept in confronting the limitations of representative democracy and strengthen its legitimacy. Moreover, the diverse theoretical paradigms that have inspired reforms made by postmodern governments and public administrations ("new governance", "new public service" and "open government") also refer to participation as one of their key pillars in governmental innovation and the improvement of public policy. These approaches advocate a kind of "citizenparticipant" (Pastor Albaladejo, 2013b) in considering citizens to be "agents that create value" in the production of public outcomes (Bourgon, 2010).primarily because they carry their own resources (capacities, experiences, competences, ideas, time, etc) so that when effectively integrated with political-administrative resources (organisational, financial, human, etc) they can be determinant in generating better public decisions and guarantee a greater degree of social wellbeing (Pastor Albaladejo and Garcia Solana, 2012).

From a practical perspective, participation is a recurrent term in the discourses employed by political and administrative authorities. Because of this there it is a growing governmental tendency to promote initiatives that integrate the voice of citizens in public matters, especially in administrations that are smaller in scale and more proximate to citizens since they tend to develop citizen participation with greater ease (Dahl and Tufte, 1973: 13). As a consequence, local government has been the territorial sphere where this issue has been most advanced (Font, Blanco, Gomà and Jarque, 2000: 115), although it has also come up against important challenges when developing these initiatives (Gonzalez, 2011: 2011). Specifically, three types of challenges are highlighted (Colino and Del Pino, 2003). Those related to the characteristics of local government, those derived from the implementation of participatory experiences, such as excessive bureaucratisation, instrumentalization and frustration of the citizenry, and those resulting from the behaviour and attitudes of the actors involved. 
Despite what has been mentioned, multiple and diverse participatory mechanisms have proliferated in the local sphere, from those that are more classical or traditional, such as stable bodies of citizen participation (for example, consultative councils). To those that are more innovative, such as face to face and / or online participatory budgets. Unlike stable bodies of citizen participation, participatory processes are characterised by their temporary nature (not durable or stable in time). their open structure (any citizen can intervene in these spaces) and by addressing specific matters (Parès and Resende, 2009: 84).

This growing (and disproportionate) tendency on behalf of local governments for implementing participatory mechanisms led us to propose a series of questions which led to this research: are all participatory initiatives promoted by municipal administrations of good quality? Which are the better quality experiences? What facets of these need to be improved to progress towards a good quality participatory model that adds public value?

Taking this into account, this article analyses two participatory processes that are linked to the urban redevelopment policy of the City of $\mathrm{Madrid}^{2}$, with the aim of evaluating the quality of these initiatives (by applying an analytical framework which is described in the second section) and, as a result, to conclude which participatory experience enjoys a greater quality. The data obtained will allow us to make a series of recommendations to improve the development of these processes (improve their quality). Moreover, the study of two similar participatory processes (that belong to the same territorial area and policy sector) will make it possible to verify that the quality of citizen participation can be different in initiatives that start from the same context (political, institutional, social and cultural) and policy sector. Therefore, the instrumental or procedural aspects make the difference and, as such, impact upon the degree of quality of these experiences.

It must also be highlighted that this research plans to contribute new knowledge on this issue, since the research on citizen participation in urban policy making are rare, and the majority of these have a theoretical-normative focus (Martinez, 2006). This gap in academic study is larger when we consider that the object of the study is the quality of participatory processes in this policy sector.

In order to meet these objectives, the article is structured in various sections. In the following section the methodological framework used in this research is explained. In the third section two participatory processes are analysed by applying different analytical variables and dimensions. Finally, a general assessment will be made, highlighting the achievements that are most significant to verify the degree of quality of the cases under study, as well as developing a series of recommendations for improvement. 


\section{Analytical and methodological approach to participatory processes at local level}

The research method which is most used by academics in political science is that of the case study. It is a theoretically informed strategy that also seeks to develop theory (Yacuzzi, 2005) and, that allows the development of empirical studies of a phenomenon in its own context (Yin, 1994). Furthermore, the case study contributes to describing and explaining the unity of in-depth analysis, inquiring into its multiple properties.

This research adopts a case study methodology, but from a comparative perspective. Specifically, the units of analysis are two participatory processes promoted by the City of Madrid. This local government has become a national and international reference point in terms of citizen participation, due to the fact that it has set in motion various initiatives since 2015. Furthermore, Madrid is the largest out of $8,122^{3}$ municipalities in Spain with its 3,182,175 residents ${ }^{4}$. The research, therefore, focuses on a large municipality and considerable activity in terms of citizen participation, which stands in contrast to the argument made by some academics that participatory experiences are more common in medium-sized rather than in large cities (Wampler, 2008).

Besides, both cases of citizen participation are linked to urban redevelopment policy - one of the most relevant policy areas at the local level and where participatory processes have been developed since the 1990's - although the majority of these took places in the most populous municipalities (Font and Rivero, 1999; Font, Gomá and Subirats, 2004). In spite of this, some authors maintain that citizen participation continues to be a pending subject within democratic urbanism (Martinez Lopez, 2006; Boira and Marqués, 2003; Navarro, 2001). For its part, the greater part of participatory processes that have been promoted by the City of Madrid in the past two years have focussed on this policy sector. This much is evidenced by participatory processes which were carried out in most districts or decentralised management units through which the administration is territorially structured. Amongst these it is appropriate to highlight the redevelopment of the "Plaza de la Vanguardia" (Fuencarral-El Pardo district); the redevelopment of the "Plaza de la Remonta" (Tetuán District); the redevelopment of "Plaza de Puerto Carfranc" (Puente de Vallecas District); and the redevelopment of the "Plaza de Duquesa de Osuna" (Barajas District). Specifically, the cases analysed are: the reform of Gran Via (Central District) and the redevelopment of the Plaza de España (Moncloa-Aravaca district). These initiatives have been selected because they differ from the previous ones in terms of the public they are focussed on. That is to say, the potential participants. In the cases of Gran Via and Plaza de España, all the citizens of Madrid can take part in the participatory processes. The other experiences differed in that they only allowed the participation of citizens that reside in the corresponding districts. 
Furthermore, Decide Madrid, the technological platform upon which these two participatory processes are based, has received the 2018 UN Public Service Prize.

In order to comparatively analyse the quality of participatory processes a series of analytical dimensions have been generated, to which a range of explanatory variables are associated that tend to be used by various scholars of citizen participation (Colino and Del Pino, 2003; Font and Blanco, 2005; 2006; Parés and Castellà, 2009; Parés, Pomeroy and Diaz, 2007; Kamlage and Nanz, 2017; McLaverty, 2017; Fitzgerald et al, 2016, inter alia). This analytical framework will help develop a systematic and comparative evaluation of the quality of both participatory processes, which will help to identify and explain the similarities and differences observed, as well as to understand which participatory processes offer a greater quality and degree of development and in what respects.

As can be seen in Table 1, four analytical dimensions have been identified: a) the initial context in which participatory processes originate (political, institutional, social and cultural context); b) the actors that initiate, promote and manage participatory processes, and especially, the social actors that take part in these (actors that are able to participate, the basis of participation - individual and/or collective, degree of representativeness and diversity); c) the instruments used to implement citizen participation (plan of action, participatory mechanisms and channels, resources and monitoring and evaluation processes); d) the effects or the results of participation (managerial results - impact of participation on public decision; political results - impact of participation upon the development of democratic values-; and social results- impact of participation upon social inclusion-). The methodology employed is distinguished by its innovative character, since most part of academic studies focus on identifying the elements that characterise participatory initiatives, explaining why they arise (contextual factors), who participates, and how participation is managed. However, the proposed analytical framework not only covers these aspects, but also, what effects/results are produced by participation, how much participation takes place, and where participation takes place, with the objective of evaluating differences between the level of quality of redevelopment processes of Plaza de Espana and the participatory process relating to the reforms of Gran Via. This is an analytical framework that is transferable (with some adaptations) to evaluating participatory processes in other local contexts. 
Table 1: Dimensions and variables for the analysis of local participatory processes

\begin{tabular}{|c|c|}
\hline Dimensions & Variables \\
\hline \multirow[t]{3}{*}{ Context } & $\begin{array}{l}\text { - Political context: support for and political commitment to } \\
\text { participation (whether or not it is included in the policy } \\
\text { programme of the governing administration or formed part of the } \\
\text { previous governing administration); ideology or political leaning } \\
\text { of the local administration; political consensus; stability of the } \\
\text { local governing system. }\end{array}$ \\
\hline & $\begin{array}{l}\text { - Institutional context: institutional and legislator framework to } \\
\text { develop participation; and agency within the municipal } \\
\text { administration with specific competences in terms of participation }\end{array}$ \\
\hline & $\begin{array}{l}\text { - Social and cultural context: citizen demands for a greater degree } \\
\text { of participation; educational level of society; and associative } \\
\text { tradition (existence of social capital). }\end{array}$ \\
\hline Actors & $\begin{array}{l}\text { - Actors that promote, coordinate and manage participatory } \\
\text { processes } \\
\text { Social actors that participate: actors that have access to } \\
\text { participation; basis of participation (individual and / or collective); } \\
\text { representativeness (degree or percentage of citizen participation } \\
\text { relative to the total citizenry registered in the municipality); and } \\
\text { social diversity of participants (gender - females and males-, age } \\
\text { - young and older people -, etc). }\end{array}$ \\
\hline Instruments & $\begin{array}{l}\text { - Strategy and action plan linked to the participatory process - } \\
\text { objectives, stages, etc } \\
\text { - } \\
\text { Resources: economic resources (budget), informational resources } \\
\text { (information to incentives participation) and technological } \\
\text { resources. } \\
\text { - Mechanisms or channels for participation (surveys, forums, etc.). } \\
\text { - Processes for monitoring and evaluating participation }\end{array}$ \\
\hline Effect/results & $\begin{array}{l}\text { - Managerial results: impact of participatory processes upon the } \\
\text { administrative model and public decisions (public policies) } \\
\text { - Political results: impacts of participatory processes upon the } \\
\text { development of the democratic political system's values. } \\
\text { - Social results: impacts of participatory processes upon social } \\
\text { inclusion and cohesion. }\end{array}$ \\
\hline
\end{tabular}

Source: Own elaboration based on analysis of various sources (Colino and Del Pino, 2003; Font and Blanco, 2005, 2006; Parés, Pomeroy and Díaz, 2007; Parés and Castellà, 2009; Pastor Albaladejo, 2014, 2013a, 2013b; inter alia).

Finally, it is important to highlight that the research is based upon various approaches to data collection. These include quantitative techniques (surveys, statistical data on participation, etc) as well as qualitative techniques (document analysis). Furthermore, primary sources (reports and statistical data from the City 
of Madrid) and secondary sources (institutional documents academic documents and news articles) have been combined.

Analysis of citizen participation processes in urban policies of the City of Madrid

As highlighted above, participatory processes are fixed term (impermanent) initiatives aimed at including the voice of citizens (whether individually or collectively) in consultation, deliberation and decision making related to public affairs.

In this section we analyze two participatory initiatives of this kind in the same policy sector (urban restructuring) and the same territorial area (the municipality of Madrid): participatory processes relating to reforms to "Gran Vía" (an important shopping and nightlife street in central Madrid), and to the refurbishment of the "Plaza de España" (a large square and important tourist destination in central Madrid).

However, these cases differ in some respects, such as their time span and the geographic area they focus on. Specifically, the participatory process focussed on Gran Vía ran for six days from the $13^{\text {th }}$ to the $19^{\text {th }}$ of February 2017, and the process focused on Plaza de España began on the $3^{\text {rd }}$ December 2015 and ended on February $19^{\text {th }} 2017$. Furthermore, whilst both processes took place in the same municipality they do not focus on the same district of the City. In this respect it should be noted that Madrid is a large municipality, and thus, following the principle of functional decentralisation, is constituted by 21 districts. Our analysis takes place in two different districts: Central district (in the case of Gran Vía) and Moncloa-Aravaca (in the case of Plaza de España). Some authors argue that decentralised administration can be favourable to citizen participation (Fung and Wright, 2001). However, this contextual variable has not been applied to the analysis of the cases considered in this research. This is because Madrid's districts do not have competencies relating to citizen participation because responsibility for this matter resides in the central administrative agencies of the municipality. Having made these clarifications, we use the following analytical dimensions to investigate the case studies: the contextual origins of the participatory initiatives; the actors (including those that promote and administer participation as well as social actors who participate in these processes), the mechanisms through which citizen participation is implemented, and the effects / results of the participatory processes.

\subsection{Context}

Contextual factors are a crucial dimension in the study of participation, above all because the tend to impact upon their performance (Lowndes and Pratchett, 2001: 
11). In order to evaluate this dimension, the relevant analytical variables are as follows: the political context (Avritzer, 2010); the institutional characteristics (Colino and Del Pino, 2003); the social context (Font and Galais, 2011); and the cultural context, or traditions in associative terms.

a) Political context

Political support and commitment is a strategic factor that impacts upon the successful development of participatory processes. Most research demonstrates a correlation between the ideology of local government and political support for citizen participation. In this sense, it is highlighted that governments made up of left-wing parties tend to have a greater degree of political commitment (Cernadas, Chao and Pineda, 2017).

The participatory processes relating to the reforms of Gran Vía and to the refurbishment of Plaza de España are promoted by "Ahora Madrid", an ideologically left-wing political party that has governed the municipality since 2015. Nevertheless, the development of citizen participation initiated in a prior period, with the consecutive centre-right administrations of the "Partido Popular" (PP). In this previous era, the "Reglamento Orgánico de Participación Ciudadana" (local regulation for citizen participation) was approved in 2004, and various initiatives were set in motion, such as participatory budgeting. The Ahora Madrid government has maintained this original institutional framework, although it has also reformed the participatory model by creating an online platform (Decide Madrid) and a new government department intended to develop citizen participation, the Department for Civic Participation, Transparency and Open Government. This information contributes to the conclusion that the ideology of the municipal government has not impacted upon the development of citizen participation because the different governments of City of Madrid (PP and Ahora Madrid) have demonstrated political support and commitment for this issue. However, the ideology or political leanings of local government can also impact on the intensity of participation. Left wing parties tend to implement processes with a greater deliberative quality or with greater impact on decision making, whilst conservative administrations tend to support participatory mechanisms of a "consumerist" nature (Colino and Del Pino, 2003). In this respect, the participatory processes that Ahora Madrid has promoted are characterised by their more inclusive nature and for extending citizen participation to other policy sectors for the first time, such as in urban redevelopment.

Nevertheless, the viability of participatory processes not only depends upon the political support of local government, but also upon the existence of a political consensus between all municipal political groups vis-à-vis citizen participation. Contemporarily, the City of Madrid has four political groups: Ahora Madrid (leftwing), Partido Socialista Obrero Español (PSOE) (centre-left), PP (centre-right) and Ciudadanos (C's) (liberals). Ahora Madrid and PSOE have demonstrated 
greater support for the cases analysed here. PP and C's have been more reluctant, claiming that low levels of citizen participation in these processes delegitimates the decisions made. Moreover, the only parties that have dedicated a specific space to citizen participation in their political programme have been Ahora Madrid and Ciudadanos, whilst the two traditional parties (PP and PSOE) have done so in a marginal way. This situation could be put down to two causes. Firstly, because emergent coalitions that enter government tend to promote citizen participation policies, either because they form part of their political programme or in order to increase their power against traditional parties (Schneider and Welp, 2011). Secondly, because strongly institutionalised parties are more resistant to losing absolute political control of the decision making process and therefore to conceding spaces of power to the citizenry (Goldfrank, 2006).

Finally, another political factor that tends to impact on participation is the stability of government. In this respect, Lowndes, Pratchett and Stoker (2006: 555) point out that during sustained periods of political stability citizen participation policies are less likely to be implemented to make decisions. When parties and leaders feel secure in their electoral support they are less inclined to concede spaces of power. When electoral competition is strong and sustained (as in the case of the City of Madrid at present), politicians and political parties are more in favour of implementing processes of dialogue with the citizenry in order to obtain greater legitimacy and support (Lowndes, Pratchett and Stoker, 2006).

b) Institutional context

The institutional context refers to the permanent, stable system that political and administrative authorities generate in order to develop and promote citizen participation in municipal public policy. The institutional system for participation revolves around two mechanisms: the regulative framework of "norms intended to institutionalise, order and promote citizen participation" (Pastor Abaladejo, 2013a:197), and the departments or institutions that are created in "ad-hoc" manner within the municipal structure, with the goal of initiating, guiding and administering participation. The analysis of these institutional mechanisms helps to understand whether the participatory processes which the City of Madrid promotes, count on an institutional support adequate to guarantee the successful development of participation in urban regeneration policy in Plaza de España and Gran Vía.

In terms of the regulatory framework, the Spanish constitution recognises the right of citizens to participate in public matters (article 23.1). Moreover, it also points out that public institutions must "[...] facilitate the participation of all citizens in political, economic, cultural and social life" (article 9.2).

Regarding local legislation, the law 7/1985 of the $2^{\text {nd }}$ April, "Regulation of the bases of the local regime" (LRBRL) highlights that local governments and 
administrations must develop organic regulations, procedures and public bodies that are appropriate to ensure the realisation of the participation of residents in matters relating to local public life. This applies both to the municipality as a whole, as well as to different districts, where these geographical subdivisions exist. ${ }^{5}$ For this reason, the City of Madrid created its own Organic Regulation of Civic Participation (Orgánico de Participación Ciudadana) (ROPC) in 2004, with the goal of developing citizen participation in accordance with the provisions made by articles 9.2 and 23.1 of the Spanish constitution.

The ROPC states that "all residents have the right to intervene directly or via their associations in the administration of public matters within their competence (art. 14) and it also identifies a range of consultative bodies (District Territorial Councils ${ }^{6}$, Sectoral Councils ${ }^{7}$ and Council Director of the $\left.\mathrm{City}^{8}\right)$ as well as a range of mechanisms to enact participation (the popular regulation initiative; the citizen initiative to promote activities of public interest, the right to propose; popular consultation and the right to an audience). Moreover, the regulations on participation grant the Mayor (if approved by an absolute majority in plenary meeting and in accordance with the provisions of local regulations ${ }^{9}$ ) the power to initiate consultation on municipal matters that are of special relevance to residents, except those that relate to the local Treasury. This precept follows the law of Local Administration in the City of Madrid 2/2003 $11^{\text {th }}$ March, where it is established that "in order to encourage the participation of residents in local government and administration, municipalities have a duty to organise popular consultations subject to the limits and prerequisites in article 71 of the LRBRL" (art. 25.1).

Besides, the City of Madrid has also generated other regulations governing participation. Those that stand out are linked to the institutionalisation of consultative bodies with social representation that are linked to certain public policies ${ }^{10}$ and the guidelines on public consultation regarding the development of municipal regulations (although budgetary and organizational regulations, fiscal ordinances and urban planning instruments are excluded from these participatory processes).

Alongside the regulatory framework, the institutional system of civic participation is also constituted by municipal administrative bodies with powers in these matters. The existence of these bodies within the municipal structure determines the level of importance that local governments concede to citizen participation. In this sense, the institutional tendency of local governments has been to create councils of participation. This evidences the will of municipal administration to take on and develop a new area of government (Salvador and Ramió, 2012).

In 2015, the City of Madrid introduced a new department in its municipal structure with a view to promoting participation: the Office of Citizen Participation, 
Transparency and Open Government. Specifically, the competencies assigned to this new body were the following: set in motion, promote and control citizen participation, facilitate cooperation, volunteering and social and promote transparency and accountability.

Therefore, the participatory processes of the City of Madrid have, in general terms, had the appropriate institutional support to guarantee their successful development.

c) Social and cultural context

The existence of a favourable social and cultural context can also be one of the boosting factors for citizen participation processes (Font, 2011).

Participatory experiences should be generated in a social environment that is receptive to participation in order for these to be truly useful and effective, and also contribute to reinforce democratic legitimacy. In this respect data from the Centre for Sociological Investigations ${ }^{11}$ (see survey 2930, of 2014) show that a high percentage of the society of Madrid (63\%) demands a "bottom-up" model of representation. As such, a majority of the population prefers a model of participatory democracy in which citizens can intervene directly in deliberative and decision making processes relating to public affairs that affect their community.

With regards to the cultural context, there are two elements that can impact positively upon citizen participation: the educational level and the participatory tradition (the level of social capital). Regarding the educational level, 825,189 citizens of Madrid have achieved a wide range of university degrees (undergraduate, diplomas, postgraduate and doctoral studies) and 976,517 have baccalaureate qualifications (or pre-Baccalaureate Spanish equivalent), respectively a percentage of $33 \%$ and $40 \%$ of the City's population. As a consequence, the society of Madrid possesses an acceptable cultural and educational level to be able to participate in public matters.

On the other hand, the associational tradition, or the characteristics of the associational fabric of a given society is a key factor in boosting citizen participation because it favours the development of deliberative abilities and the co-ordination of joint action (Fung and Wright, 2003; Avritzer, 2010). The society of Madrid has a long-standing experience in neighbourhood-based association. Proof of this is that seven resident-led movements were differentiated in the 1970's (Castells, 1977: 76-83). ${ }^{12}$ Contemporarily, a great amount of associations have proliferated in Madrid, in defense of different interests ranging from educational, cultural and neighbourhood-based (Alba, Navarro y Garcia, 2005). ${ }^{13}$ Moreover, a part of these tend to collaborate with the municipal administration in the production and management of public goods and services. 
In spite of the above, the tradition in associative terms and the cultural and educational level of the people of Madrid are variables that have not had a positive impact in the involvement of the citizens of Madrid in both the participatory processes analysed here. Specifically, the low levels of civic participation denote a lack of interest and commitment on behalf of citizens regarding matters that affect their local community.

\subsection{Actors}

The actors constitute analytical dimensions that allow us to understand who has intervened in the participatory processes relating to the reform of "Gran Vía" and the refurbishment of the "Plaza de España". Two types of actors can be identified that carry out different roles in these cases: public actors that promote, lead and co-ordinate participatory processes; and social actors that intervene by expressing their opinions and / or co-deciding with public actors in their respective cases.

a) Public actors

Public actors are those individuals and organisations that belong to a political administrative environment, so they are institutionally linked to the organisational structure of government and / or public administration (Pastor Albaladejo, 2014: 33).

Different public actors from the City of Madrid have intervened in the cases of participation analysed here. The direction and leadership of participatory processes has been carried out by the Department of Citizen Participation, Transparency and Open Government (a body that is charged with promoting citizen participation in the City's public matters), and, in particular, by one of its units, the General Sub-directorate of Citizen Participation and Volunteerism (a body that is subordinate to the General Directorate of Citizen Participation).This actor also exercises transversal competencies in terms of citizen participation, by virtue of which it joins up on occasion with some sectoral departments or services of the municipal administration in order to define and / or develop a certain phase of the participatory project. Furthermore, the department of citizen participation also intervenes alongside other public and / or social actors in spaces for debate and deliberation. In the case of the refurbishment of "Plaza España", it has interacted with a diversity of actors (resident associations, professional groups, charities, affected residents, political authorities from municipal districts and professionals from the department of Climate Change and Mobility as well as the Department of the Economy and Public Finance of the City of Madrid) in working groups aiming to identify the problems and expectations of the people of Madrid in order to design the online questionnaire for citizen participation.

Another key actors in the cases analysed (which is linked to urban policy) was the General Directorate of Urban Strategy (a body which is subordinate to the 
Department of Sustainable Urban Development). This municipal body took responsibility for carrying out an initial diagnosis of the urban reforms to "Plaza de España" and "Gran Vía", including a redesign of the plan to reform "Gran Vía". Furthermore, it developed for each participatory process a series of documents ${ }^{14}$ that were made available to citizens with the aim of ensuring these had access to the necessary information to respond to the surveys. Keeping in mind the responses that obtained majority in the surveys, it took charge of developing and publishing the documents to be used in the bidding process for the refurbishment of each space. Moreover, in the case of "Gran Vía", it not only did it prepare the tender document but also decided upon it].

In the case of the refurbishment of the "Plaza de España" the General Directorate of Urban Strategy took part in the committee which was created to evaluate received proposals and vet these against the conditions established in the call for proposals. The committee was composed of diverse public actors and experts in the sector: the Department of Environment and Mobility (one representative); the Department for Sustainable Urban Development (Advisor of the Representative and General Directorate of Urban Strategy); the Department of Citizen Participation, Transparency and Open Government (one representative); the Government Department of Culture and Sport (General Directorate for Intervention in the Urban Landscape and Cultural Heritage); one representative from the PP parliamentary group and another from Ciudadanos; the Official College of Architects of Madrid (Representative and Sub-director of Commissioning); the Official College of Engineers of Roads, Canals and Ports (Dean, and expert in infrastructure); the Legal Advice service and the Auditor general of the council.

On the other hand, within this same government department, the General Subdirectorate for the Control of Urbanization took charge of determining the viability of the consultations relating to the refurbishment projects in both areas of the city.

Finally, in the case of "Plaza España", the Department of the Environment and Mobility and the Department of Culture and Sport (General Directorate for Intervention in the Urban Landscape and Cultural Heritage) took part in the selection of the proposed projects, and therefore their opinion was taken into account when determining the characteristics of these. The Local Historical Heritage Commission (subordinate to the regional administration of the Autonomous Community of Madrid) approved the refurbishment and construction projects in this Madrid square, following an impact study.

b) Social actors

Social actors are "individuals and organized (or disorganised) groups that form part of society" (Pastor Albaladejo, 2013a) and can intervene in participatory 
processes. For this reason, the analysis of this variable will contribute to knowing which social actors can access these processes as well as the basis upon which participation takes place, whether individual and / or collective. Moreover, the results of each initiative will reveal the representativeness (the level or percentage of citizen participation relative to the total number of citizens registered in the municipality) and the diversity of participants in these processes.

The system through which citizens access participatory processes is one of the factors that impact on the quality of these initiatives. In this respect, the two participatory processes considered here are characterised by openness. That is to say, any citizen that is 16 years of age or above and is registered in Madrid could take part in these. As such, an inclusive and democratic model for access has been generated, since these processes are open to the society of Madrid (without exclusions or discriminations) so that it may freely take part, dedicating their time to, and sharing their opinion on, the improvement of urban redevelopment of the city.

The basis of participation is the same in both cases analysed here (individual and collective), although different experiences are noted based on the different phase or stage of the participatory process. Specifically, individual (or personal) and collective (through organised social groups) participation was carried out at the beginning of each participatory process ${ }^{15}$ in the face to face meetings that were called to present and debate proposals, although the residents associations and different city groups ${ }^{16}$ were the most active actors in this phase. In the case of the refurbishment of "Plaza de España", EUROPAN (a social entity and forum for debate on housing, architecture and urban planning that is concerned with the development of cities) was part of the competition jury, and as such took part in the selection of the final projects.

However, individual participation was considered in the voting phase of the questionnaires in both cases, as well as when voting on proposals for the redevelopment of the "Plaza de España".

Regarding representativeness, the level of citizen participation has been very low in the proposal voting stage and was therefore not very representative. In the case of the participatory process relating to the redevelopment of "Plaza de España" three ballots were held. The level of participation was as follows (see table 2): $0.84 \%$ of the population registered in the city in the first vote; $0.23 \%$ in the second; and $6.6 \%$ in the third. The degree of representativeness has increased, although this figure continues to be insignificant in relation to the total population. In the participatory process relating to "Gran Vía", participation was also low, at $2.6 \%$. 
Another analytical variable related to participatory processes is the degree of diversity of the social actors involved, especially considering that Madrid has a diverse society. As can be seen from table 2, females participated to a lesser degree than males in the "Plaza de España" process, although this pattern is reversed in the case of "Gran Vía". In terms of age, the City of Madrid has only made data available relating to the voting on "Plaza de España", where we can see that young people and those above 65 years of age took part to a similar degree, although the digital divide tends to reduce the participation of older people.

Table 2: Representativeness and diversity of citizen participation

\begin{tabular}{|l|c|c|c|c|}
\hline Process & \multicolumn{3}{|c|}{ Plaza de España } & Gran Vía** \\
\hline & 1 st Vote & 2nd Vote & 3rd Vote* & Vote \\
\hline $\begin{array}{l}\text { Total No } \\
\text { (participant \%) }\end{array}$ & $\begin{array}{c}28.249 \\
(0,84 \%)\end{array}$ & $\begin{array}{c}7.613 \\
(0,23 \%)\end{array}$ & $\begin{array}{c}183.476 \\
(6,6 \%)\end{array}$ & 83.101 \\
\hline Females & $\begin{array}{c}10.466 \\
(37 \%)\end{array}$ & $\begin{array}{c}3.017 \\
(39,63 \%)\end{array}$ & ---- & ---- \\
\hline $\begin{array}{l}\text { Young people } \\
\text { (up to 24 years of } \\
\text { age) }\end{array}$ & $\begin{array}{c}1.986 \\
(7,4 \%)\end{array}$ & $\begin{array}{c}794 \\
(10,43 \%)\end{array}$ & ---- & \\
\hline $\begin{array}{l}\text { Older than 65 years } \\
\text { of age }\end{array}$ & $\begin{array}{c}2.061 \\
(7,68 \%)\end{array}$ & $\begin{array}{c}484 \\
(6,36 \%)\end{array}$ & ---- & --- \\
\hline
\end{tabular}

Source: Authors' elaboration based on data collected by Decide Madrid (City of Madrid)

* Madrid City Council has yet to publish the disaggregated data.

** Madrid City Council has yet to publish the disaggregated data

\subsection{Instruments}

The quality of participatory processes also depends on the instruments used to implement and develop these initiatives.

A key instrument in participatory processes is the action plan. The existence of this administrative tool demonstrates foresight and planning related to citizen participation, as well as a commitment to the continual improvement of these processes. The redevelopment of "Plaza de España" and the reforms to "Gran Vía" were two initiatives that formed part of the city of Madrid's Sustainable Urban Development Plan, and therefore its aims were included in this sectoral plan. In the case of "Plaza de España", the objectives were very wide: rebuild the pedestrian infrastructure of the area, generate new open air spaces and improve existing ones, promote a programme for leisure and commerce, develop sustainable urban space and link the square with the different urban spaces that surround it. In Gran Vía, on the other hand, the objective was to improve pedestrian mobility and urban transport. 
In order to decide on the scope of each intervention, the City of Madrid decided to create a public hearing, even though the type of participatory process was different in each case. In the redevelopment of "Plaza de España" a "complex public hearing" was chosen whereby it was necessary to decide on the sustainability and scope of the proposal, and a proposal would be selected to carry out the intervention. In the reform to "Gran Vía" a "simple public hearing" ${ }^{17}$ was chosen; that is to say, a deliberative process that allowed the collection of citizen proposals for the improvement of pedestrian mobility and urban transport.

Nevertheless, the City of Madrid has not developed an action plan specifically to manage these participatory processes, instead there are several municipal provisions that refer to these initiatives. Based on a consultation of these, and in order to assess each initiative, each participatory process has been broken down into different phases and stages which they are made up of, including the resources, the instruments of participation and processes for monitoring and evaluation.

Tabla 3: Phases o etapas de los procesos participativos

\begin{tabular}{|c|c|}
\hline $\begin{array}{l}\text { Participatory process for the redevelopment } \\
\text { of Plaza de España }\end{array}$ & $\begin{array}{l}\text { Proceso participativo de reforma } \\
\text { de la Gran Vía }\end{array}$ \\
\hline $\begin{array}{l}\text { - Phase 1: Debate and working groups } \\
\text { - Phase 2: External communication } \\
\text { - Phase 3: Citizen consultation } \\
\text { - Phase 4: Project tendering } \\
\text { - Phase 5: External communication } \\
\text { - Phase 6: Citizen consultation for the } \\
\text { evaluation of projects } \\
\text { - Phase 7: Evaluation of projects by } \\
\text { committee and publication of results } \\
\text { - Phase 8: Final citizen vote between two } \\
\text { finalist projects, and publication of } \\
\text { results for winning project } \\
\text { - Phase 9: Technical consultation } \\
\text { - Phase 10: Development of tender } \\
\text { specifications and project award }\end{array}$ & 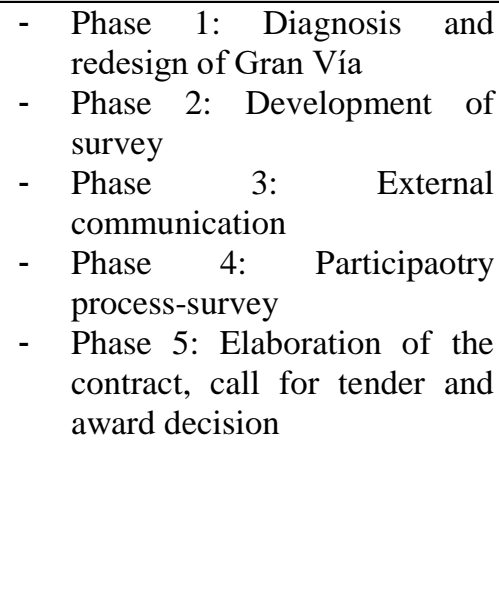 \\
\hline
\end{tabular}

Source: Authors' own elaboration based on data collected by Decide Madrid (City of Madrid) and the Official College of Architects of Madrid.

As can be seen in table 3, the participatory process relating to the redevelopment of "Plaza de España" took place in ten phases:

- Phase 1: Debate and working groups. In this phase three debates took place to determine how to integrate the square within the neighbourhood and City, as well as how to guarantee the mobility, natural environment and energy. Having 
gathered this information, meetings were convened in which public actors (representatives and officers from City hall) and a diversity of social actors (residents associations, urbanists, hoteliers etc) participate. These led to the development of reports about the scope of the intervention and to the development of the questions in the citizen survey.

- Phase 2: external communication. The General Directorate of Urban Strategy (which forms part of to the Department or Sustainable Urban Development) developed a series of documents which it made available to citizens in order that these would be informed vis-à-vis responding to the survey in the next phase.

- Phase 3: citizen consultation. The citizen consultation stage began on the $28^{\text {th }}$ of December 2015 and lasted 40 days. In this period, citizens could participate through a survey made up of eighteen questions which was available on the online platform "Decide Madrid". 28,249 people took part in this process, although only 26,961 votes were valid. The majority responses from the surveys were turned into the compulsory basic elements for the international tender for the redevelopment of the "Plaza de España".

- Phase 4: project tendering. In this phase the General Directorate for Urban Strategy developed and published the tender document for the presentation of proposals for the redevelopment of the "Plaza de España". Following this, the committee for the "tendering of ideas for the redevelopment of the Plaza de España of Madrid" was established in the headquarters of the Official College of Architects of Madrid in order to ensure that proposals met the conditions of the cal.

- Phase 5: external communication. Seventy proposals selected by the committee were published on he Decide Madrid website, in order to allow citizens to consult these. A media campaign was also developed to inform and involve citizens in the participatory process.

- Phase 6: citizen consultation for the evaluation of projects. In this new consultation, citizens evaluated the projects and voted on the 70 of these.

- Phase 7: Evaluation of proposals by committee and publication of results. Following the consultation a committee was put together composed of diverse political-administrative actors (the representative from the department of Sustainable Urban Development - who acted as chair-; members of different municipal departments - amongst which was the representative from the Department of Citizen Participation, Transparency and Open Government-; and municipal officers) and by social actors (representatives from the Official College of Architects of Madrid; the Official College of Engineers of Roads, Canals and Ports, as well as architects, engineers and distinguished expects in urban development). The aim of this body was to evaluate the projects selected by citizens and select a few of these to be submitted to a citizen vote. Initially, five projects were selected and further information requested from their proposers in order to initiate a further round of evaluation. In this second 
phase, the committee selected two final projects out of the initial five, and then published the results on the web platform Decide Madrid.

- Phase 8: final vote and publication of results. The two final proposals were put to a final vote which began on the $13^{\text {th }}$ February and ended the $19^{\text {th }}$ February 2017. The winning proposal was "Welcome Mother Nature", which achieved $51,99 \%$ of the valid votes cast. Following this, the Department for Citizen Participation, Transparency and Open Government proceeded to publish the results via various channels, including the Decide Madrid website.

- Phase 9: technical consultation on the viability of the winning proposal. Following the vote, the General Directorate for Urban Strategy consulted external experts as well as the Local Heritage Committee (a public body belonging to the Autonomous Community of Madrid) on the viability of the winning project. The results of this consultation resulted in a modification to the original project.

- Phase 10: development of tender specifications and award of the project. Towards the end of 2018 the General Directorate for Urban Strategy developed and published the tender specification for the redevelopment of the Plaza de España.

The participatory process relating to the reform of Gran Vía was less complex than that above, and was composed of 5 phases (see table 3). In phase 1 the Department for Citizen Participation, Transparency and Open Government and the Department for Sustainable Urban Development carried out a diagnosis of the situation. Moreover, the General Directorate for Urban Strategy (which belongs to the Department of Sustainable Urban Strategy) took responsibility for drafting the information document about the analysis and diagnosis relating to the urban reform of Gran Vía based on a series of consultations with residents associations and experts. In phase 2, the General Directorate for Citizen Participation and the general Secretary for Citizen Participation and Volunteerism developed the four questions on the survey intended to evaluate the appropriateness of the reform of Gran Vía and its surroundings, as well as the pedestrianisation of this street. In phase 3, an information campaign was carried out in order to raise awareness amongst citizens about these participatory processes and the objectives of Gran Vía reforms. In phase 4 the vote was called for the $13^{\text {th }}$ and $19^{\text {th }}$ of February of 2017, although the results were not made public until the $27^{\text {th }}$ February of 2017. In phase 5, the General Directorate for Urban Strategy developed the tender specifications for proposals based on the results of the surveys. The tender was not made public until the last quarter of 2017. Twenty entities responded to the tender, although it was finally awarded to the company "Ortiz Construcciones y Proyectos".

On the other hand, participation needs the allocation of resources, understood as elements that add value to the participatory process because they guarantee its viability and therefore contribute to the ability of these initiatives to meet their 
objectives and achieve the results expected of them. The following are analysed: economic resources, informational resources and technological resources.

Regarding economic resources, the City of Madrid allocated 1,1 million Euros to the preparation, dissemination and the start-up of the participatory processes. This budget is more than sufficient to guarantee that both processes to take place.

Information is another resource that contributes to increasing the quality of participatory processes, primarily because governments and public administrations should make their participatory actions be known well in advance in order to attract and involve the largest possible number of citizen participants, and thereby strengthen the legitimacy of the decisions made. Specifically, the City of Madrid carried out an intensive publicity campaign to inform citizens about these participatory processes. Multiple channels were used in doing so: posters, advertising spots in various media, information on the municipal website and social networks, telephone calls and posting documents to the residents of Madrid.

In the case of the redevelopment of the Plaza de España, all necessary information was made available to citizens in advance of the first ballot, and an online space was created in Decide Madrid called "doubts about the participatory process on the possible intervention in Paza Espana" in order to allow citizens to consult procedures and their scope. Moreover, the seventy proposals received were published on the municipal website, and all the paperwork generated by each proposal was made physically available in the Plaza de España. Nevertheless, two difficulties have been highlighted in relation to information: the overloading of information (consulting such an exhaustive corpus of paperwork requires much time) and the technical language of the paperwork. With regards to the second ballot the procedure was practically identical. However, there were just two proposals, thereby considerably reducing the amount of paperwork to consult. In the case of the redevelopment of Gran Vía, there was much less information provided because the participatory process took on board fewer options. It solely consisted of responding to four simple questions.

Both participatory processes have counted on a crucial technological resource: the Decide Madrid online platform. This virtual space has been used as a dissemination channel for information and results, as well as a tool to vote on surveys and proposals. This technological instrument not only made the participatory processes transparent, bit also facilitated access to them, because the citizens were able to consult the information made available and vote from their homes without having to travel). For this reason it was the means of voting which was used the most in the participatory processes, according to the data provided by the City of Madrid. 
The mechanisms, or channels, of participation in the cases analysed were broader in the case of the redevelopment of Plaza de España. In this case, the Decide Madrid website was used so that citizens could answer a questionnaire made up of eighteen questions intended to determine the bases for the redevelopment tender. Following this, four channels were opened for voting on proposals: online surveys; face to face surveys in twenty-six citizen service offices; a telephone questionnaire; and a postal questionnaire sent through a franked envelope. In the case of the redevelopment of Gran Vía the same mechanisms were used apart from the telephone survey.

The questionnaire to determine the bases for the redevelopment tender in Plaza de España was different to that of Gran Vía (see table 4). The Gran Vía questionnaire was composed of four questions, whilst the Plaza de España questionnaire had eighteen. This was not the only difference however. The Plaza de España survey was developed through a participatory process in which members of local government, representatives of associations, universities and specialists (amongst others) intervened and interacted. Moreover, the questions on the Gran Vía survey were closed with three options (Yes, No or Blank vote). The questions for Plaza de España put forward various possibilities in order to define the preference of citizens, some even allowed for multiple responses. In this way citizens could express their preferences regarding different aspects related to the square and its surroundings. For example, from whether it was deemed necessary to intervene to reform the square in the first place, and, should it be deemed so what type of reform should be carried out and what should be the spatial scope of the reform; to opinions about the use of the square as well as the buildings that it is made up of and their purpose should be; the vegetation and monuments on the square; the mobility, connectivity and accessibility, underground parking or the overpass, etc.

Table 4: Comparative analysis of the surveys used on the two participatory processes

\begin{tabular}{|c|c|}
\hline Type of survey & Content / questions \\
\hline $\begin{array}{l}\text { Citizen survey for the } \\
\text { reform of Gran Vía }\end{array}$ & $\begin{array}{l}\text { 1) Do you agree with improving the pedestrian space of } \\
\text { Gran Vía by extending its sidewalks? } \\
\text { 2) Do you feel that it is necessary to improve the } \\
\text { conditions of the rear seats linked to the Gran Vía so that } \\
\text { they can be used as a place to rest and / or stay? } \\
\text { 3) Do you think it would be necessary to increase the } \\
\text { number of pedestrian crossings of the Gran Vía to } \\
\text { improve pedestrian communication? } \\
\text { 4) Do you agree that public transport must still be } \\
\text { prioritized in the road traffic on the Gran Vía? }\end{array}$ \\
\hline
\end{tabular}




\begin{tabular}{|l|l|}
\hline $\begin{array}{l}\text { Citizen survey for the } \\
\text { redevelopment } \\
\text { Plaza de España }\end{array}$ & $\begin{array}{l}\text { 1a) Do you think it is necessary to reform the Plaza de } \\
\text { España? } \\
\text { 1b) Do you think that it is necessary that the reform of } \\
\text { the Plaza de España should also affect adjoining areas } \\
\text { and the streets through which it is connected? } \\
\text { 2) Do you think that pedestrian connections between } \\
\text { Plaza de España with the following spaces should be } \\
\text { improved? } \\
\text { 3) Do you think it is necessary to limit some of the } \\
\text { following uses? } \\
\text { 4) What uses or roles would you like Plaza de España to } \\
\text { carry out? } \\
\text { 5) In general terms, how would you like Plaza de España } \\
\text { to be? } \\
\text { 6) Amongst its monuments the Square includes the } \\
\text { monument to Cervantes, what do you feel would be the } \\
\text { best option? } \\
\text { 7) Currently the underground of the square has } \\
\text { commercial space. What use would you prioritise for this } \\
\text { space? } \\
\text { 8a) Do you think that the square should be part of a green } \\
\text { network that extends from Casa de Campo and Parque } \\
\text { del Oeste to the centre of the city? } \\
\text { 8b) What do you think should be done with the trees that } \\
\text { are currently in the square? } \\
\text { 9) The design of the square should prioritize the needs of } \\
\text { a? } \\
\text { 10) What actions do you think are necessary regarding } \\
\text { the traffic in the vicinity of the Plaza de España? } \\
\text { 11) What do you think should be done with the overpass } \\
\text { of Bailén? } \\
\text { 12) Regarding the existing parking spaces in the Plaza de } \\
\text { España ... } \\
\text { 13) Do you think that the construction works in the Plaza } \\
\text { de España should be carried out in such a way that the } \\
\text { environmental impact is minimised, even if this implies } \\
\text { an increase in cost? } \\
\text { 14) What measures of environmental sustainability would } \\
\text { you like to be taken account of in the design of the Plaza } \\
\text { de España? } \\
\text { 15a) how do you use this space? } \\
\text { 15b) How do you move about in the Plaza de España? } \\
\text { 16) What new uses of the square would expel you from } \\
\text { the area? }\end{array}$ \\
\\
\end{tabular}




\begin{tabular}{|l|l|}
\hline $\begin{array}{l}\text { 17) What services, activities or uses do you think are } \\
\text { missing, or are unwanted? } \\
\text { 18) Finally, if a reform to Plaza de España is carried out, } \\
\text { of what type do you think it should be? }\end{array}$ \\
\hline
\end{tabular}

Source: Author's own elaboration based on the information on the Decide Madrid website.

Finally, the participatory processes must count upon a system of monitoring and evaluation that contributes to the continual improvement of these initiatives. However, in the cases considered here these kinds of instruments were not considered to be fundamental for the quality of participatory processes.

\subsection{Effects / Results}

The quality of participatory processes is also measured by its effects or results. In this sense participation implies the establishment of a "new strategy and modus operandi in the process of public policy development, which implies a transition from traditional approaches to a model of public policy made with and for citizens" (Pastor Albaladejo, 2013a: 196). In this model citizens are not merely passive subjects of policy, but also active agents that collaborate in decision making on matters which affect their communities with political and administrative actors. In this way, the results of participation not only contribute to legitimating public policies, but also to reinforcing the values of representative democracy and to guarantee greater social inclusion and cohesion. As a consequence, participatory process of high quality should produce three kinds of public value: managerial, political and social value.

a) Managerial value

The impact of citizen participation in the urban redevelopment policy of the City of Madrid has been different in each case.

In the redevelopment of the Plaza España the final results of the participatory process had a direct impact upon binding public decision making, even if some changes were made to the project chosen by the citizenry (following viability assessment carried out by technical experts). Nevertheless, these changes did not impact upon the preferences expressed by citizens.

In the participatory process relating to Gran Vía, the citizens were consulted on their preferences regarding the pedestrianisation of this public space. Nevertheless, the final decision on the nature of the reform was taken by the City of Madrid.

Therefore, if the impact of citizen participation upon policy making is taken into account, the quality of the participatory relating to the redevelopment of the Plaza de España is greater than that relating to the reform of Gran Vía. This is mainly because, as per Arnstein (1969) ladder, the first coheres with a co-governance 
approach (the highest level of citizen participation, where citizens take part in decision making processes that are binding in nature) and the second is a consultation (citizens select an option, but they do not decide).

b) Political value

The quality of citizen participation can also be measured by its impact in the development of the principles and values of the representative democratic political system. These include, inter alia, liberty, equality, transparency and accountability.

The two cases allowed citizens to participate freely (choosing freely whether or not they would like to dedicate their time to taking part in participatory processes) and on an equal basis, for each citizen that is registered in the municipality (even if they do not reside in the affected districts) enjoyed the same opportunities to take part in these processes if they wished to do so.

In relation to transparency, this was guaranteed by the participatory process relating to the redevelopment of the Plaza de España. This is because the City of Madrid made the information related to each initiative available to the public (such as the general parameters; the most asked questions; the studies carried out into the issue; the working documents; and the results of the surveys and votes). However, in the participatory process relating to Gran Vía less information was made available to the public, such as the questions asked, information about what the plans were and the results of the survey vote. Moreover, in both cases, there was an informational deficit regarding the managers responsible for leading and administering these processes, as well as their economic cost. On the other hand, the usage of the online platform Decide Madrid increased the transparency of these participatory experiences because any interested citizen was able to consult information made available in one space (procedural accessibility), in any moment (temporal accessibility) and without having to travel (spatial accessibility).

Accountability was partially realised in both cases, this is primarily because public actors responsible for the redevelopment only accounted on the results of the initiatives, and not on their impacts due to the lack of a system for monitoring and evaluation that would collect such information.

c) Social value

Participation must be considered as "the first, and most important, step if we really wish to create an increasingly cohesive society" (Brugué, 2009: 227). As a consequence, participation favours social cohesion and inclusion, as well as in generating a culture and "civic consciousness, that constitutes the basic energy that sustains participation" (Villoria et al., 2005: 23). 
The analysis of the two participatory processes has demonstrated that they are open and inclusive. All citizens can take part in them, without discriminating on the basis of gender, race, age, ideology or religion. Nevertheless, inclusion deficits, related to citizens with some kind of sensory disability have been identified. Specifically, the Decide Madrid platform lacks a program that can convert text into audio so that the blind might also be informed and involved in participatory processes. The same applies to the deaf, or people with hearing impairments, since the web lacks readers that can turn text into touch reading. The information made available on paper to citizens also failed to make these provisions.

Moreover, the low level of social participation in these initiatives denotes a lack of interest from the society of Madrid to take part in matters of public import in their local community. As a consequence, the deficit of active citizenship and participatory culture, which stands in stark contrast with the associational culture in Madrid, has impacted negatively upon social inclusion and cohesion.

\section{Conclusions}

The comparative analysis of the participatory processes linked to urban redevelopment policy in the City of Madrid has allowed an investigation into the quality of these initiatives, as well as verification that the process relating to the redevelopment of the Plaza de España is of greater quality. Nevertheless, it has also been found that the differences between each process primarily revolve around procedural, or instrumental, aspects. In any case, it has been evidenced that each initiative should, to a greater or lesser extent, reform processes in order to improve their quality and generate greater public value.

Specifically, both cases took place in a context which was clearly favourable for the successful development of citizen participation. The development of participation was supported by the Municipal government (led by a left-wing political party which had risen relatively recently to power) who demonstrated political commitment to these, as did the rest of the political groups. Moreover, the institutional framework was appropriate to promoting participation. The right to participation is recognised in municipal law; an organic law on citizen participation was developed as well as a government department with specific competences in matters of participation. Moreover, the society of Madrid demanded greater direct involvement in public matters, and also had the appropriate capacity for this (appropriate educational level and experience in resident associations). Nevertheless, this favourable social context did not lead to the substantive involvement of the people of Madrid in the participatory processes analysed here. The low level of participation denotes a lack of interest and commitment on part of citizens regarding public matters in their local community. 
Besides, leadership of participatory initiatives was carried out by public actors, principally those in the Department of Citizen Participation, Transparency and Open Government, who hold the responsibility to promote participation in transversal fashion. Another key actor was the Department for Sustainable Urban Development (via the General Directorate of Urban Strategy). This body carried out an active role in the management of the processes, realising the initial diagnosis for both processes, and elaborating all the necessary information to inform decisions made by citizens, which was disseminated well in advanced of the exercise of the right to participate. Furthermore, in the case of Gran Vía, the design of the reform plan intervened. These two political-administrative actors have interacted with other social and public actors (citizens and organised social groups) in various deliberative spaces (e.g. the committee in the participatory process relating to the redevelopment of the Plaza de España). Social actors have been able to intervene freely (without exclusions) in the participatory processes, either in mixed fashion (as individuals and as part of collectives) at the beginning of each collaborative process, or in individual fashion. In this sense, there was a greater degree of individual participation in the case of the redevelopment of the Plaza de España, since the citizenry could participation by voting on proposals and through the survey. In case of the reform to Gran Vía, however, they could only do so by taking part in the survey.

The greatest quality deficits and differences between both cases revolve around the procedural aspect of the processes. Specifically, in order to be fully implemented, participation should not only form part of the municipal government's strategy, but should also be accompanied by an action plan that defines the following aspects: the goals and aims of participation; what part of the public can take part in participatory processes; public officials and their roles and responsibilities; the resources assigned; the actions that will be carried through; the estimated implementation time; and the monitoring and evaluation mechanisms. In neither of the two cases is such an action plan envisaged that encompasses and guides participatory processes to avoid inefficiency and ineffectiveness. For this reason it is an aspect that should be strengthened in order to increase the quality of these processes.

In terms of resources, it should be noted that citizen participation cannot be implemented at zero cost, since every kind of initiative (face to face and / or online) should be accompanied by a budget that allows for its development as well as its temporal continuity. The City of Madrid has designated an important part of the budget to the development of these participatory processes. However, there is no publicly available information about how much finance is devoted to each process. It is recommended that this information should be published in order to increase transparency. 
Moreover, both cases are also characterised by their use of a technological resource, the Decide Madrid online platform, which has made an important contribution to the quality of both participatory processes. This is because it has innovated the form of participation, which is traditionally face to face, favoured accessibility and has had a positive impact on the level of participation, since it was the most used channel for voting in those ballots that allowed for other participatory mechanisms (such as in the case of the redevelopment of the Plaza de España).

Information is another resource that increases the quality of participatory processes. In both cases a communication strategy was lacking that clearly defined the objectives of each participatory phase (ex ante, in via and ex post), as well as the measures to achieve these, in order to motivate and involve citizens in these initiatives, since participation cannot be developed without them. For this reason, it is to be recommended that public institutions carry out citizen education and social awareness campaigns via a range of channels (social networks, institutional websites, radio, television, etc) with a view to informing citizens about the existence of these kinds of initiatives and motivate them to take part. Moreover, at the beginning of the process, participants should be clearly informed about the "rules of the game" (objectives, topic in question, methods, schedule, etc), as well as making available, via open access, all possible information and data about the topic to be debated. During the process of participation (in via), the objective of the communication strategy should be to involve and motivate those that take part in the process. For this reason information should reinforce and help maintain the involvement and commitment of citizens taking part in participatory processes, especially when the cases under consideration have used an online channel (Decide Madrid). Once the process is finished (ex post) the results should be disseminated with the aim of reinforcing confidence between the participating actors, as well as the broader social confidence in these kinds of initiatives. As such, the management of this kind of strategic communication will help increase the transparency of the process and strengthen its democratic legitimacy.

In terms of channels of participation, the design of questionnaires can impede or enable citizen freedom of choice. For this reason, it is important to develop clear questions where different options can be decided upon. In this sense, the survey of the process related to Gran Vía clearly restricted participation. In contrast to the process related to the Plaza de España, the questions were developed without collaborating with citizens. It is logical to propose that citizens will find it easier to understand these questions given that they have taken part in their development and definition.

Both cases have not implemented processes of monitoring and evaluation, which has impacted negatively upon them. This is mainly because monitoring and evaluation facilitate the continuous improvement and generates institutional 
learning about these kinds of initiatives, which can be shared. That is to say, transferred to other contexts, to other public organisations who wish to implement citizen participation. For this reason, it is proposed that process evaluation should be institutionalised via the establishment of a stable and permanent agency tasked with studying, monitoring and evaluation citizen participation. Some of the powers and functions of this agency (which could be called the "Citizen Participation Observatory") could be, amongst others, the following: encouraging theoretical and empirical research on this phenomenon; establishing indicators for monitoring citizen participation; measuring the managerial/administrative impact (the effects of participation upon the improvement of public policies) the political impact (effects of participation upon the values of representative democratic political system) the social impacts (effects of participation upon inclusion and cohesion) and to advise municipal bodies in the development of participation initiatives.

Finally, citizen participation the results have generated public value in the cases analyze, although to a different degree according to the type of dimension: managerial, politics and social. The managerial, the impact of public participation upon binding urban redevelopment policy was greater in the case of the redevelopment of the Plaza de España, since it adopted a model of co-governance. Gran Vía, on the other hand, adopted a consultative model. Moreover, they are entirely innovative because they are related to the important sector of city planning where, as we have pointed out in this article, participatory processes are more symbolic than real.

In terms of political value, the high level of inclusiveness should be noted. Citizens have been able to take part freely and under equal conditions, without any kind of discrimination. However, it should also be noted that in the case of the process relating to the Plaza de España there was a greater involvement of the citizenry throughout the process. This is due to the higher level of information and dissemination, which has resulted in a greater degree of democratization than in the case of Gran Vía. In any case, both cases overcame the pitfalls of city planning processes. That is to say, poor interaction between the citizenry, and the failure to generate dynamic processes that transcend the most rigid technocratic and regulatory constraints.

Finally, the social value produced can also be considered to be considerable. This is principally because, as we have just mentioned, both processes opted for a high degree of inclusiveness. Despite this, it is true that there remains considerable space for improvement. For example, the Decide Madrid online platform did not develop any tools which would allow disabled people (e.g. the blind and the deaf) to be informed about, and involved in, the process. Moreover, the paper-based information that was made available did fully compensate for this. Those within the City of Madrid responsible for designing and administering these kinds of 
processes, should have developed a process of social awareness, which would have contributed to increasing the participatory culture of Madrid's citizens. This might have avoided, even if partially, the low levels of participation witnessed in both cases.

In conclusion, it should be highlighted that local governments should begin to change focus in the way they approach citizen participation and opt for quality instead of quantity (multiple mechanisms that do not add public value) with the aim of reinforcing democracy and regaining some of the legitimacy which it has lost.

\section{Notes:}

1 The quality of democracy (Diamond and Morlino, 2004; Morlino, 2007) is a recent theoretical approach that provides a series of dimensions to assess the degree of development of democracies.

${ }^{2}$ The Council is the central government body and institution for municipal administration in Spain.

${ }^{3}$ Data from the Spanish Ministry of "Hacienda y Funcion Publica" (Treasury) from 2017.

4 The City of Madrid is made up of 21 municipal districts that are in turn divided in neighborhoods

${ }^{5}$ See articles 68 and 70 of the LRBRL.

6 The Territorial Councils of the Districts are "bodies of participation, consultation, information and suggestion regarding municipal performance, which allow the participation of residents, their associations and civic entities of a district in the management of municipal affairs. Its essential purpose is to promote joint reflection among citizens, their associations and the municipal authorities, on the issues that affect the daily lives of the districts and neighbourhoods, making possible a responsible involvement of the citizens in municipal management"(Article 54 of the ROPC).

7 The City Council creates "these consultative participatory bodies that channel the participation of residents and their associations in large sectors or areas of municipal action. Its purpose is to provide advice and consultation to those responsible for the different areas of municipal action "(Article 60 of the ROPC).

${ }^{8}$ The City's Board of Directors is "a consultative and governing body of the city of Madrid, whose fundamental mission is to offer a strategic thinking space for the management of public affairs in the city. The fundamental goal of this body is to establish the vision of success for the future of Madrid and to develop a strategic perspective that guides and serves as support for the management of the main issues and public affairs of the city "(Article 65 of the ROPC).

9 See article 71 of the LRBRL and Law 2/2003, of March 11, on Local Administration of the Community of Madrid

10 There are various regulations on this matter. The following stand out: the regulation for the functioning of local forums in Madrid's districts; the regulation for the functioning of the territorial councils of the districts; the Regulation for the Organization and Functioning of the Madrid Forum for Dialogue and Cohabitation of the City of Madrid; the Regulation of the Organization and Functioning of the Volunteers Council; and the Regulation of Organization and Functioning of the Forum of Solidarity of the City of Madrid. 
${ }^{11}$ The Centre for Sociological investigations (Centro de Investigaciones Sociológicas) is a Spanish state body that carries out periodic scientific studies about Spanish society.

12 The seven associative groups of Madrid are: movements in social housing neighbourhoods; movements in temporary housing neighbourhoods; movements in residential zones of social housing; movements in peripheral zones of private development; movements of residential complexes in the immediate periphery of the City; movements of exclusive residential developments; and movements of various sectors against the transformation of the center of Madrid (Castells, 1977: 76-83).

1319.350 associations are registered in the City of Madrid (Data from the City of Madrid: www.madrid.org).

${ }^{14}$ In the case of the redevelopment of Plazas de España, the documents related to two different matters: the historical evolution of the section of the City being redeveloped; the environmental and scenic quality; the situation of the greenery; the social-demographic characteristics of the immediate surroundings; road traffic issues; pedestrian circulation; the condition of the pavements; flooring; and the urban landscape, amongst others. In the case of reforms to Gran Via, the was a lesser quantity of documents developed (and disseminated) since the objective of this project was to improve mobility within this urban space.

${ }^{15}$ Reference is made to phase 1 (debat and working groups) of the participatory process of Plaza de España and phase 1 (redesign of Gran Via) of the Gran Via process, that are addressed in section 3.3 of the article

16 Amongst the associations and collectives that frequented the working meetings the following stand out: Confederation of Associations of Consumers and Service Users of Madrid (CECU), Entorno Conde Duque, Entorno Plaza de los Cubos, Coordinator of Central Madrid Neighbourhood Association; College of Civil Engineers, Canals and Ports, La Viña. Hotel Management Association, Madrid Business Forum, Madrid Citizenship and Heritage, Urban Debate Club, VP Hotels, etc

17 The Madrid City Council Agreement of September 15, 2016 approved the simplified guidelines for the development of public hearings.

\section{References:}

Alba, C., Navarro, C. \& García, E. (2005) Descripción del tejido asociativo del municipio de Madrid (Madrid: Informe del Ayuntamiento de Madrid).

Arnstein, S. (1969) A ladder of citizen participation, Journal of the American Institute of Planners, 35, pp. 216-224.

Avrtizer, L. (2010) Las instituciones participativas en el Brasil democrático (Universidad Veracruzana, México).

Bourgon, J. (2010) Propósito público, autoridad gubernamental y poder colectivo, Revista Reforma y Democracia, 46, pp. 5-40.

Brugué, J. (2009). Políticas para la cohesión social: Nuevos contenidos y nuevas formas, In: Pascual Esteve, J. M. \& Pascual Guiteras, J. (eds.) Cohesión Social y Gobernanza democrática: Para unas regiones y ciudades más inclusivas (Sevilla: Junta de Andalucía)

Castells, M. (1977) Ciudad, democracia y socialismo. La experiencia de las asociaciones de vecinos de Madrid (Madrid: Siglo XXI). 
Cernadas Ramos, A., Chao Pérez, L. \& Pineda Nebot, C. (2017) Participación ciudadana: De la participación en la gestión a la gestión de la participación, Política y Sociedad, 54 (1), pp. 163-189.

Colino, C. \& Del Pino, E. (2003) Gobiernos locales e impulso democrático las nuevas formas de participación ciudadana en los gobiernos locales europeos (Madrid: Fundación Alternativas).

Colino, C. \& Del Pino, E. (2003) ¿Qué significa la participación ciudadana en el gobierno local? Concepciones, formas y límites: Criterios de valoración e instrumentos de promoción, In: Colino, C. \& Del Pino, E. (eds.) Gobiernos locales e impulso democrático: Las nuevas formas de participación ciudadana en los gobiernos locales europeos (Barcelona: Fundación Alternativas, Diputación de Barcelona).

Dahl, A. R. \& Tufte, E. R. (1973) Size and democracy (Palo Alto: Stanford University Press).

Diamond, L. \& Morlino, L. (2004) The Quality of Democracy. An Overview, Journal of Democracy, 15(4), pp. 20-31.

Fitzgerald, C., McCarthy, S., Carton, F., O'Connor, Y., Lynch, L. \& Adam, F. (2016) Citizen participation in decision-making: Can one make a difference?, Journal of Decision Systems, 25(1), pp. 248-260.

Font, J. \& Galais, C. (2011) The qualities of local participation the explanatory role of ideology, external support and civil society as organizer, International Journal of Urban and Regional Research, 35(5), pp. 932-948.

Font, J. \& Rivero, C. (1999) Participación de la sociedad civil en el desarrollo estratégico urbano y territorial, In: Subirats, J. (ed.) ¿Existe sociedad civil en España? Responsabilidades colectivas y valores públicos (Madrid, Fundación Encuentro, pp. 362-406).

Font, J. (2011) Democracia local en Andalucia. Experiencias participativas en los municipios andaluces (Sevilla: Centro de Estudios Andaluces).

Font, J. and Blanco, I. (2005) Qué hay detrás de la oferta de participación? El rol de los factores instrumentales e ideológicos en los mecanismos españoles de participación, Revista del CLAD Reforma y Democracia, 31, pp. 1-17.

Font, J. \& Blanco, I. (2006) Experiencias de participación ciudadana. Polis, la ciudad participativa. Participar en los municipios: ¿Quién?, ¿Cómo? y ¿Por qué? (Barcelona: Diputación de Barcelona).

Font, J., Blanco, I., Gomà, R. \& Jarque, M. (2000) Mecanismos de participación ciudadana en la toma de decisiones locales: una visión panorámica. Caracas: Tercer Premio, XIV Concurso de Ensayos del CLAD “Administración Pública y Ciudadanía”.

Font, J., Goma, R. \& Subirats, J. (2004) La participación ciudadana. Diagnóstico, experiencias y perspectivas". In: EFA-CAP, La participación ciudadana como eje trasversal de la gestión municipal: Planes, iniciativas y mecanismos de participación (Madrid: Escuela de Gestión Pública-Consultores de Administraciones Públicas).

Fung, A. \& Olin Wright, E. (2003) Democracia en profundidad. Nuevas formas institucionales de gobierno participativo con poder de decisión (Bogotá: Universidad Nacional de Colombia).

Goldfrank, B. (2006) Los procesos de presupuesto participativo en América Latina: Éxito, fracaso y cambio, Revista de Ciencia Política, 26(2), pp. 3-28.

González Salcedo, A. (2011) Los desafíos de la participación ciudadano local. Un estudio comparado entre ciudades Helsenki y Madrid, Revista del CLAD, Reforma y Democracia, 49, pp. 205-240. 
Kamlage, J. H. \& Nanz, P. (2016) Crisis and participation in the European Union: Energy policy as a test bed for new politics of citizen participation, Global Civil Society Participation, 31, pp. 65-82.

Lowndes, V. \& Pratchett, L. (2009) Factores que explican la participación: Comparando recursos, relaciones y normas en cinco países europeos, In: Parés, M. (eds.) Participación y calidad democrática. Evaluando las nuevas formas de democracia participativa (Barcelona: Ariel).

Lowndes, V., Pratchett, L. \& Stoker, G. (2006) Local political participation: The impact of rules-in-use, Public Administration, 84(3), pp. 539-561.

Martínez López, M. (2006) La participación social en el urbanismo en los límites de la realidad, Boletín $C F+S, 34$, pp. 71-80.

McLaverty, P. (2017) Public participation and innovations in community governance. (New York: Routledge).

Morlino, L. (2007) Explicar la calidad democrático, Revista de Ciencia Política, 7(2), pp.322.

Navarro, C. (2001) Límites y contingencias de la democracia asociativa. Gobierno municipal y asociaciones cívicas en Italia y España (1960-1995), In: Font, J. Ciudadanos y decisiones públicas (Barcelona: Ariel, pp. 95-110).

Parés i Franzi, M. \& Resende, P. E. R. (2009) Roles, estructura y funcionamiento de los espacios estables de participación ciudadana, In: Parés i Franzi, M. (ed.). Participación y calidad democrática: Evaluando las nuevas formas de democracia participativa (Madrid: Ariel, pp. 167-188).

Parés, M. and Castellà, C. (2009) Una propuesta de criterios de calidad democrática para evaluar los procesos participativos. In Participación y calidad democrática. Evaluando las nuevas formas de democracia participativa. (Barcelona: Ariel).

Parés, M., Pomeroy, M. \& Díaz, L. (2007) Guía práctica para la evaluación de la participación (Barcelona: OIDP).

Pastor Albaladejo, G. (2013a) El sistema institucional de participación ciudadana en las políticas y servicios sociales de la Comunidad de Madrid, Revista CastellanoManchega de Ciencias Sociales, 15, pp. 195-205.

Pastor Albaladejo, G. (2013b) Nuevo Servicio Público y Participación. Ponencia en el XI Congreso Nacional de la Asociación Española de Ciencia Política y de la Administración. Sevilla, 18 al 20 de septiembre.

Pastor Albaladejo, G. (2014) Teoría y Práctica de las Politicas Públicas (Valencia: Tirant lo Blanch).

Pastor Albaladejo, G. \& García Solana M. J. (2012) La colaboración público-privada en los servicios de atención a las personas con discapacidad física de la Comunidad de Madrid. In: Bañón, R., Tamboleo Garcia, R., Sanchez Medero, G. (eds.) Participación, Democracia y Gestión de la Escasez: Experiencias de gobiernos territoriales, de gestión de la innovación y del cambio, y de políticas y servicios públicos (Madrid: Instituto Complutense de Ciencia de la Administración).

Salvador, M. \& Ramió, C. (2012) El diseño institucional de la participación ciudadana en la administración local: Reflexiones a partir de un estudio de caso, Revista del CLAD, 53, pp. 165-186.

Schneider, C. \& Welp, Y. (2011) ¿Transformación democrática o control político? Análisis comparado de la participación ciudadana en América del Sur, Iconos. Revista de Ciencias Sociales, 40, pp. 21-39.

Villoria, M., Iglesias Alonso, Á. \& Delgado Godoy, L. (2005) La participación ciudadana en las grandes ciudades (Madrid: Universidad Rey Juan Carlos y Dikinson). 
LEX LOCALIS - Journal of LoCAL SELF-GovernMENT

G. Sánchez Medero \& G. Pastor Albaladejo: The Quality of Participatory Processes in the Urban Redevelopment Policy of Madrid City Council

Wampler, B. (2008) Participatory budgeting in Brazil: Contestation, cooperation and accountability (University Park, Pennsylvania State Press).

Yacuzzi, E. (2005) El estudio de caso como metodología de investigación: Teorías, mecanismos causales y validación, CEMA Working Papers, 296, pp. 1-37.

Yin, R. K. (1994) Case Study Research. Design and Methods. London: Sage Publications. 